\title{
Livermore official linked with alleged spy
}

Geoff Brumfiel, Washington

The head of counterintelligence at Lawrence Livermore National Laboratory in California has resigned following revelations that he had a sporadic, 15-year affair with an alleged Chinese spy.

William Cleveland, a former special agent with the Federal Bureau of Investigation (FBI), resigned from his position at the nuclear-weapons laboratory on 10 April, after ten years in charge of its counterintelligence office. His resignation preceded press revelations that an official matching Cleveland's description had a relationship with Katrina Leung, a prominent ChineseAmerican community leader and Republican Party fundraiser. Leung worked for the FBI but is now accused of working as a double agent for China. She was arrested on 9 Apri and is in prison awaiting trial. Cleveland has not been charged with any offence and is cooperating with the authorities.

"The allegations in the affidavit are personal in nature, and there is absolutely nothing in it to indicate that security was compromised at Livermore," Susan Houghton, a

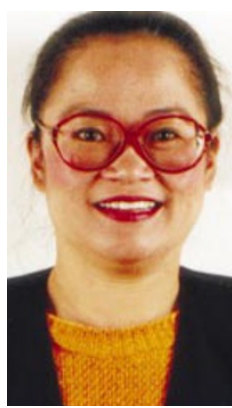

Katrina Leung: accused of spying for China. they will conduct their own investigation.

The main allegations against Leung involve her relationship with FBI agent James Smith, who handled her work for the bureau. It is not clear how much, if any, information allegedly passed by Leung to China involved the Livermore laboratory. But she seems to have some knowledge of the investigation of a scientist there, Peter Lee, who confessed in 1997 to leaking nuclear-weapon and subma- rine secrets to China. According to the FBI affidavit, a search of Leung's residence in December 2002 turned up a list of telephone numbers for 'Royal Tourist', the codename for the FBI's investigation into Lee.

Cleveland was said to be well respected at the lab, where he trained researchers and managers on how foreign agents might try to befriend them to gain classified secrets. $\mathrm{He}$ was also responsible for debriefing scientists who had travelled to sensitive countries or recently hosted foreign visitors. "He was a superstar of counterintelligence at the Department of Energy," says Peter Stockton, who served as a security consultant to former energy secretary Bill Richardson, and now works with the Washington-based Project on Government Oversight.

The latest espionage case could carry adverse consequences for the laboratory or its contractor, the University of California, which is already under fire for its management of Los Alamos National Laboratory in New Mexico (see Nature 421, 99; 2003), and for an earlier, inconclusive spying probe involving Wen Ho Lee, a researcher at Los Alamos.

\section{Partners dig deep for ocean-drilling project}

\section{Geoff Brumfiel, Washington}

Japan and the United States are set to forge ahead with a major drilling collaboration to explore what lies beneath the ocean floor.

The two nations are expected to sign a deal next week that will commit US\$1.2 billion over ten years to the operating costs of the Ocean Drilling Program. And although Europe won't take part in the Tokyo signing ceremony, ocean scientists are optimistic that it will come on board later.

The deal, which succeeds an existing agreement that expires this September, will deploy two ships equipped with advanced drilling technology to take core samples from the ocean floor, including from areas that have previously been inaccessible.

The US National Science Foundation (NSF) and the Japanese Ministry of Education, Culture, Sports, Science and Technology (MEXT) have each agreed to bear $44 \%$ of the estimated $\$ 150$-million annual running costs of the programme, and the hope is that Europe will make up the deficit. The agreement marks "a visionary new phase in scientific ocean drilling", says Jeff Fox of Texas A\&M University in College Station, the director of scientific operations for the existing international programme.

Japan and the United States are already planning to build the two vessels that will do most of the programme's work. Japan is spending $\$ 500$ million on Chikyu, a vessel that will be able to bore up to six kilometres into Earth's crust.

"This new ship will try to understand the physical and chemical environment off Japan's coasts, where many earthquakes occur," says Ted Moore, a marine geologist at the University of Michigan in Ann Arbor, who co-chairs the new programme's scientific review committee.

In addition, Moore says that the ship will allow scientists to learn more about the formation of Earth's crust and to sample the huge fans of sediment that lie in the deep ocean. These sediment fans, which are deposited on the edge of continental shelves, may be one of the most complete sources of information on the planet's climate history.

The United States is planning to spend $\$ 90$ million on a more modest drilling vessel, probably a refurbished version of its current ship, the JOIDES Resolution. This could be ready next year, whereas the Chikyu is expected to enter service in 2006.

A European consortium of scientists sought funds for a full one-third participation in the new programme, but was unable to secure funding under the European Union's Sixth Framework Programme. European researchers are still planning to participate through smaller, targeted drilling projects, says Chris Franklin, head of Earth science and technology at Britain's Natural Environment Research Council, and chairman of the consortium. "Europe is striving hard to provide a way of funding this science in 2004," he says.

www.oceandrilling.org

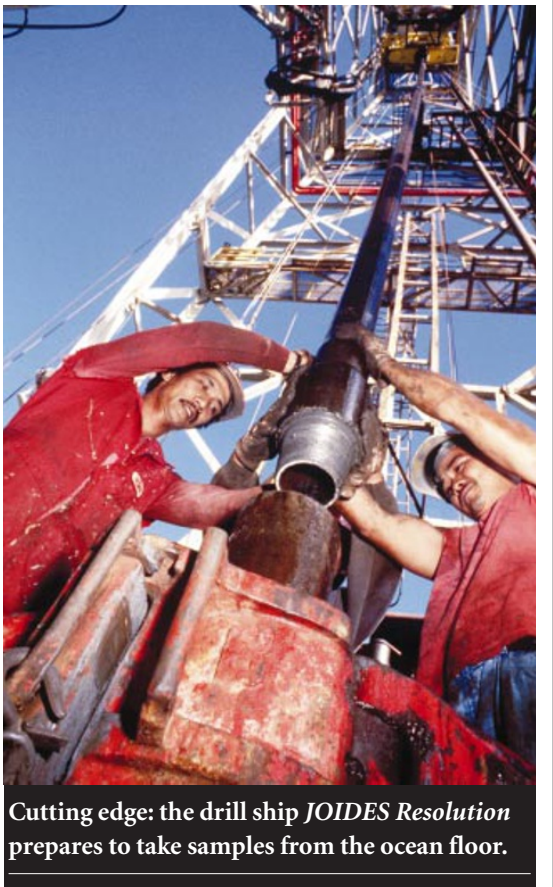

